\title{
Toxic Masculinity in Africa and the Bible: The Strong-man Model and the Co-optation of Feminist Biblical Interpretation
}

\author{
ROBERT WAFAWANAKA (VIRGINIA UNION UNIVERSITY)
}

\begin{abstract}
The present article discusses the concept of toxic masculinity in the context of African political history, leadership models and feminist biblical interpretation. It explores and problematises the idea of manliness as a key concept of masculinity exhibited in the African context by warrior queens and perpetuated by modern African leaders. The essay will demonstrate that such masculinity is toxic and it uses this backdrop to investigate how feminist biblical scholarship interpret the portrayal of women characters in the Bible. This approach uncovers a tendency by feminist scholars to interpret some biblical women characters (such as Sarah, Hagar, Yael, Rahab, Jezebel, and Abigail) in a toxic way - as strong men, or even better men. As a result, feminist scholarship unwittingly contributes to toxic masculinity by presenting women who outdo men. The goal of this article is to expose the potential for co-optation of feminist biblical interpretation by toxic masculinity. This observation leads to an alternative and contextual reading of women characters in the Bible in a non-toxic way that potentially rehabilitates them. The ramifications of reading biblical women in a non-toxic way have potential implications for reading biblical men in a non-strong-man and non-toxic way.
\end{abstract}

KEYWORDS: Masculinity, Strong-man, Biblical Interpretation, Warrior queen, African Leadership

\section{A INTRODUCTION}

Feminist biblical scholarship tends to portray biblical women as "strongmen" female characters, contributing to and reinforcing toxic masculinity or an obsession with power. This problem exists in African political history, which serves as the cultural context of this analysis. Their ancient women leaders emulate the strong-man leadership model that contemporary male leaders have perpetuated for ages. This essay argues that by critiquing patriarchy and focusing on women characters and their "manly" acts, feminist biblical interpreters and

\footnotetext{
* Submitted: 06/05/2021; peer-reviewed: 26/10/2021; accepted: 16/11/2021. Robert Wafawanaka, "Toxic Masculinity in Africa and the Bible: The Strong-man Model and the Co-optation of Feminist Biblical Interpretation," Old Testament Essays 34 no. 3 (2021): 806 - 834. DOI: https://doi.org/10.17159/2312-3621/2021/v34n3a9.
} 
their envisioned politics unwittingly co-opt toxic masculinity instead of dismantling it and rehabilitating violent biblical women.

The essay is organised into three major sections. The first section explores 'strong-man' women (i.e. warrior queens) in Africa and illustrates how these women reinforce leadership models based on toxic masculinity, still perpetuated by modern African strong-man leaders. Accordingly, toxic behaviours of African leaders illustrate the larger cultural, political, and real-life consequences of feminist biblical interpreters who idealise female biblical characters as strongman figures. Strong-man biblical women are not better men but problematic and even dangerous political figures. The second section addresses the problem of a strong-man leadership model that exists in feminist biblical interpretations of female characters as strong men or better men. This analysis criticises the strongman leadership model that feminist interpreters admire and use to portray female biblical characters. Select feminist interpretations exemplify this tendency in the field of biblical studies. Among the biblical women discussed are Sarah and Hagar (Gen 16:1-16; 21:8-21), Yael (Judg 4:17-23; 5:24-31) and Rahab (Josh 2:9-13). The third section provides an alternative reading to the strong-man model. It offers two examples of biblical women who serve justice in the world without being interpreted as toxic male leaders; this will illustrate that feminist biblical interpreters do not need to read women characters as strong-man characters. The section demonstrates how to read the selected biblical women characters without reinforcing the strong-man leadership model. This part thus offers feminist biblical scholars an alternative model that helps to avoid the idealisation of strong-man women. Among the female characters are Jezebel (1 Kgs 16:29-34; 21:1-29; 2 Kgs 9:30-37) and Abigail (1 Sam 25:1-42). The conclusion addresses the implications of reading biblical texts in a non-toxic way for feminist biblical scholarship and the ramifications for androcentric biblical interpretation.

\section{B THE STRONG-MAN MODEL IN ANCIENT AND MODERN AFRICAN POLITICAL HISTORY}

Once upon a time, gender distinctions and roles were clear and specific but Queen Hatshepsut of the eighteenth-century Egyptian Dynasty (1505-1485 B.C.E.) liked to be addressed as "he" and she wore a beard. Her masculine performance illustrates that over the millennia women, too, were victims of the strong-man ideology and fell prey to the allure and illusion of toxic masculinity. The strong-man ideology is characterised by the pursuit of power and victory at any cost. In Africa, masculinity traditionally has been associated with men and male physical attributes, performances and accomplishments but their women leaders also have often been co-opted into dominant male behaviours which helped them to succeed. Women assuming masculine roles have thus not only expanded the notion of masculinity but also reinforced masculinity's central claims. The "manly" acts of characters are a penchant for strength, violence, war, 
domination of others, killing and avoidance of weakness. Researchers argue that masculinity is a social construct and not a biological attribute, which means that it is possible that women too can exhibit typical male behaviours. ${ }^{1}$ Therefore, female masculinity is possible in both the ancient and contemporary worlds. This is exhibited in contemporary culture and around the world, from Albanian male women to early Christian male women represented by transsexual men, tomboys, and nuns dressing and acting like monks in early Christianity. ${ }^{2}$ According to Ovidiu Creangă,

Biblical masculinities is the study of the representation/s of the male gender...in biblical and related literature...it is about studying male and/or female characters and their 'manly' acts. It is the multiple deor re-constructions of the gender in biblical literature that drives the investigation, not the sex of the character/s examined. ${ }^{3}$

This essay argues that, by focusing on women characters and their manly acts in texts and society, feminist biblical exegesis and politics unwittingly have been co-opted to embrace toxic masculinity instead of dismantling it. The following few examples illustrate the strong-man model exhibited by African warrior queens.

Some of Africa's most influential women have been "warrior queens" who embody the aggressive type of masculinity noted here, act like men and defy gender-specific female roles. For instance, Queen Hatshepsut was the first warrior queen in African history. She became a pharaoh in 1473 B.C.E. when her father died without a male heir in 1493/92 B.C.E. ${ }^{4}$ Queen Hatshepsut strengthened Egypt's position, made peace with Kush (Nubia) and ruled well for

1 See Ovidiu Creangă and Peter-Ben Smit, Biblical Masculinities Foregrounded (Sheffield: Sheffield Phoenix, 2014), 4-5. Due to centuries of the domination of biblical studies by men, men's studies and the focus on women in feminist and gender studies, biblical masculinity studies emerged as a counter discipline that focuses on men and their construction in biblical texts and ancient literature. Hence, there are points of intersection and divergence among these disciplines. See the programmatic essay and comprehensive bibliography in Stephen Moore, "O Man, Who Art Thou...?' Masculinity Studies and New Testament Studies," in New Testament Masculinities (ed., Stephen D. Moore and Janice C. Anderson; Semeia 45; Atlanta: Society of Biblical Literature, 2003).

2 Peter-Ben Smit, Masculinity and the Bible: Surveys, Models, and Perspectives (Leiden: Brill, 2017), 22. See also Caroline Vander Stichele and Todd Penner, Contextualizing Gender in Early Christian Discourse: Thinking Beyond Thecla (London: T\&T Clark, 2009).

3 Creangă and Smit, Biblical Masculinities Foregrounded, 4-5.

4 History.Com Editors: https://www.history.com/topics/ancienthistory/hatshepsutaccessed March 30, 2021. See also Donald B. Redford, Ed., The Oxford Encyclopedia of Ancient Egypt (3 vol.; Oxford: Oxford University Press, 2000), $1: 168-69,233-34 ; 2: 85-87 ; 3: 57,224-25$. 
twenty-one years. She is often described as "one of the outstanding women of all time" 5 because she did not only subvert traditional gender roles and patriarchal notions but also adapted them as a powerful female leader. As the historian Diedre Wimby observes, she became a "true Horus" who created "a new science of rulership, the essence of which was the female manifesting male attributes... She donned male attire, had herself depicted with a king's beard." ${ }^{6}$ Queen Hatshepsut also preferred to be called "he." Perhaps to some feminists her leadership might seem attractive but critics should not miss that this strong warrior queen authenticated herself by acquiring and exhibiting masculine attributes and habits. The typical pharaoh was a male ruler who wielded strength, claimed divine status and commanded absolute loyalty. Queen Hatshepsut employed the strong-man ideology to succeed like a male pharaoh in ancient Egypt.

Other African warrior queens behaved like men and succeeded in spheres normally dominated by men of wealth, power and prestige. Such female rulers governed effectively but had to embrace male attributes first. They are defined by some of masculinity's chief traits - a penchant for power, war and aggression. The following examples serve to illustrate this view.

In seventeenth-century Angola, a warrior queen named Nzingha fought the Portuguese in their conquest of the country and expansion of the slave trade. When she became Queen of Ndongo in 1623, she subverted traditional female roles and "forbade her subjects to call her Queen."7 Like Queen Hatshepsut of Egypt, "She preferred to be called King and, when leading her army in battle, dressed in men's clothing." 8 In addition, "She was astute and successful in consolidating power." 9 Her leadership was not challenged because "she possessed both masculine hardness and feminine charm." ${ }^{10}$ A legend states that subjects would fall to their knees and kiss the ground at her approach. Like Queen Hatshepsut of Egypt, Queen Nzingha also subverted female roles because "she was obliged to dress as a man and kept a 'harem' of young men dressed as

5 John H. Clarke, “African Warrior Queens,” 125, in Black Women in Antiquity (ed. Ivan Van Sertima; New Brunswick: Transaction Books. 1984, Fourth printing 1986), 123-34. David Sweetman calls her "the most powerful woman to dominate the country [Egypt] since it had come into being," and the ancient world's "most outstanding female personality," Sweetman, Women Leaders in African History, African Historical Biographies (London: Heinemann, 1984), 1, 3.

6 Diedre Wimby, "The Female Horuses and Great Wives of Kemet," in Black Women in Antiquity, 46. See also Sweetman, Women Leaders in African History, 6.

7 Clarke, "African Warrior Queens," 130.

8 Ibid.

9 Ibid. She was "a great head of state and a military leader with few peers in her time," Ibid., 129. Nzingha also commanded a female army that fought alongside men.

10 Clarke, "African Warrior Queens," 130. 
women who were her "wives." 11 While she was able to impede Portuguese expansion, she also essentially had to become a man in order to consolidate her rule. These behaviours and attributes are not born in a vacuum but shaped by the dominant ideology of the time. The behaviour of these two queens supports this contention. Their effectiveness as rulers depended on their adoption of male behaviours and characteristics. These characteristics are also evident in the next two warrior queens of Africa.

Two modern African female leaders were successful as warrior queens, but they, too, had to prove themselves on the battlefield. In 19th century Ghana, Yaa Asantewaa, Queen Mother of Edweso, waged the "Yaa Asantewa[a] War" to drive out the British from the Gold Coast. ${ }^{12}$ She inspired her female warriors with these challenging words:

If you the men of Ashanti will not go forward, then we will. We the women will. I shall call upon my fellow women. We will fight the white men. We will fight till the last of us falls in the battlefields. ${ }^{13}$

Her courage and inspiration led to Ghana's eventual independence in 1957. According to Pashington Obeng, "Yaa Asantewaa was able to embody senior masculinity in a political crisis because she was a senior person herself and because she was of a royal lineage and connected with significant religious power." 14 Due to her role and authority in Asante culture, she is described as one of "female senior men." 15 As noted above, Asantewaa is famous for her belligerent attitude, another distinguishing feature of masculinity. In a different part of Africa, another female leader also exhibited the same characteristics.

At the turn of the century in Zimbabwe, a female leader and spirit medium named Nehanda emerged to resist British colonialists between 1863 and 1898. She formed an armed resistance movement with a nearby male medium named Kagubi. They successfully fought the British but eventually surrendered and were hanged in 1898. Her courage and determination were evident because she "continued to cry out her fierce resistance" even as she was being led to be

11 Sweetman, Women Leaders in African History, 45-46. Nzingha is described as an Amazon or female warrior.

12 Clarke, African Warrior Queens," 133. It should be noted that native Ghanaians spell her name as "Asantewaa," but non-natives misspell it as "Asantewa."

13 E. A. Eddy, Ghana: A History for Primary Schools, cited by Clarke in Black Women in Antiquity, 133.

14 Pashington Obeng, "Gendered Nationalism: Forms of Masculinity in Modern Asante of Ghana," in Masculinities in Modern Africa (ed. Lisa A. Lindsay and Stephan F. Miescher; Portsmouth: Heinemann, 2003), 193. Obeng, "Gendered Nationalism," 199 notes that some men attempted to argue that Yaa Asantewaa was a man disguised as a woman (ibid.).

15 Obeng, "Gendered Nationalism," 205. 
hanged. ${ }^{16}$ The martyrdom of Nehanda and Kagubi inspired the first Chimurenga liberation struggle that eventually led to the independence of Zimbabwe in 1980 during the second Chimurenga war. ${ }^{17}$ Nehanda and Kagubi remain revered liberation heroes in Zimbabwe today because of their quest for freedom. Like Queen Hatshepsut, Queen Nzingha and Yaa Asantewaa, Nehanda also had to prove herself in battle to become a successful female leader.

Part of her success was her association with Kagubi, the male spirit medium. What connects these female warrior queens of Africa is their aggression and identification with male habits, behaviours and even appearance. These women exhibited "manly" attributes as defined by men. One can argue that their leadership styles and rule were influenced by male patterns of behaviour. They did not just choose to identify as male or behave like men for no good reason. Their behaviour was "prescribed" behaviour by the prevailing dominant ideology.

The toxic masculinity apparent in African warrior queens is still perpetuated by modern African strong-man leaders. Accordingly, the toxic behaviours of many African leaders illustrate the larger cultural, political and real-life consequences of such leadership and its implications for society. A few modern African leaders illustrate the toxic strong-man syndrome and abusive leadership.

In the twentieth century, several masculinity traits have defined male politicians in Africa. ${ }^{18}$ African masculinity has been defined as "a cluster of norms, values, and behavioral patterns expressing explicit and implicit expectations of how men should act and represent themselves to others." 19 The

16 Sweetman, Women Leaders in African History, 95.

17 See Titus L. Pressler, Transfigured Night: Mission and Culture in Zimbabwe's Vigil Movement (Pretoria: University of South Africa Press, 1999), 65-98. For British history in Zimbabwe, see Robert I. Rotberg and Miles F. Shore (collaborator), The Founder: Cecil Rhodes and the Pursuit of Power (Oxford: Oxford University Press, 1988). As the title, "The Founder," shows, the British renamed the country of Zimbabwe as "Rhodesia" after Cecil John Rhodes, the so-called "discoverer" of the country but the name was restored to Zimbabwe at independence in 1980 when many other institutions and places also regained their native names rather than the corrupted names used by the British.

18 For a comprehensive study of masculinity themes in Africa, see Lisa A. Lindsay and Stephan F. Miescher, eds., Men and Masculinities in Modern Africa (Portsmouth: Heinemann, 2003). See also Dorothy L. Hodgson and Sheryl A. McCurdy, eds., "Wicked" Women and the Reconfiguration of Gender in Africa. Social History of Africa (Portsmouth: Heinemann, 2001); Mechthild Reh and Gudrun Ludwar-Ene, eds, Gender and Identity in Africa (Hamburg: Münster, 1995); S. O. Murray and W. Roscoe, eds., Boy-Wives and Female Husbands: Studies of African Homosexualities (New York: St Martin's Press, 1998).

19 Lindsay and Miescher, Men and Masculinities in Modern Africa, 3. 
chief characteristics of the strong-man syndrome are adherence to power, a penchant for violence, corruption and war-mongering.

Masculinity studies helps to shed light on the behavioural patterns of Africa's postcolonial rulers. Many strong-man leaders can be identified on the African continent in its relatively short period of about six decades of independence. Such leaders crave idolisation and wield excessive power and control over their nations. They often rule through strong-man measures like repression, corruption, intimidation, violence or fear-mongering. The strongman syndrome in Africa is what George Ayittey refers to as the "big man syndrome" and he explores more of their defining characteristics such as: obsession with power, posturing, intolerance of dissent or indifference to the welfare of citizens, among others. ${ }^{20}$ I will explore some of these traits and how they relate to key concepts of masculinity.

African strong-man leaders are defined by an insatiable quest for power and control and have ruled for an average of 30 or more years. They stay in power not because of democratic processes but due to questionable political policies or as the outcome of a one-party state rule. Strong-man rulers essentially have ruined the postcolonial African political system. They have contributed to current debilitating conditions such as extreme poverty, war or tribal conflict. This is astonishing since Africa is the world's richest continent in terms of natural resources. ${ }^{21}$ Nonetheless, despite such wealth, Africa continues to struggle with grinding poverty, misery and political and economic instability. ${ }^{22}$ These and other problems can be laid squarely at the feet of African political leaders.

The evidence implicates African government leadership, not the people in general, as the major cause of much suffering in Africa. Among many causes of the crises, the greatest are official corruption, kleptocracy, quest for political power and lack of democracy. Notably, of the 54 African countries, only about 16 are democratic. ${ }^{23}$ In several well-researched books, Ghanaian author, George B.N. Ayittey, documents how corrupt male leaders ruined Africa and he outlines a blueprint for Africa's renewal and future. ${ }^{24}$

20 George B. N. Ayittey, Africa Unchained: The Blueprint for Africa's Future (New York: NY: Palgrave Macmillan, 2005), 407.

21 The Economist (14 September 1996), 68, cited in George B. N. Ayittey, Africa in Chaos (New York: St. Martin's Press, 1998), 5-6.

22 Ayittey, Africa in Chaos, 3.

23 See ibid., 204, 350. Ayittey names 14 democratic countries but in Ayittey, Africa Unchained, 15, he increases the number to fewer than 16. Some now count 55 African countries including South Sudan.

24 See George B. N. Ayittey, Indigenous African Institutions (Doobs Ferry: Transnational Publishers, 1991); idem., Africa Betrayed (New York: St. Martin's Press, 1992); idem., Africa in Chaos; idem., Africa Unchained. 
There are two predominant views about the causes of Africa's political and economic instability. The external view (advanced by governments) blames Africa's problems on outside forces such as the twin legacies of slavery and colonialism. The internal view (advanced by the suffering peasant masses and a new generation of young African intellectuals) implicates bad African governments, economic mismanagement, military dictatorship or lack of freedom and democracy. ${ }^{25}$ Ayittey refers to those who hold the external view as the "hippo" generation and those who hold the internal view as the "cheetah" generation. The hippo generation fought for independence but is "intellectually astigmatized and stuck in their colonialist pedagogy." 26

[The cheetah generation] can take Africa in a new direction. Their minds are not polluted with all this anticolonialist rhetoric and garbage. As such, they are capable of clear thinking, can see things with acute clarity, and can understand that the leadership must be held accountable for the mess in Africa. ${ }^{27}$

Despite this bleak picture, the political landscape of Africa has changed and many citizens no longer deify their leaders even when their freedom of expression is at risk. ${ }^{28}$ In addition, the hippo generation is on its way out as many of the liberation leaders are no longer alive, which makes one wonder whether the conditions in Africa will finally improve.

The problem of strong-man rule and dogmatic adherence to power and control is illustrated by several African male leaders. The struggle for free expression in Zimbabwe demonstrates this reality. At independence in 1980, Zimbabweans revered then Prime Minister (and later President) Robert Mugabe. Songs of his praise were sung everywhere; clothing items were emblazoned with his image; but disillusionment with Mugabe's regime and his dictatorial tendencies eventually settled in over his 37 years in power. Mugabe clung to power vowing that only God would remove him. Zimbabweans witnessed gradual winds of change including contest of more than 20 parties in the 2018 election. ${ }^{29}$ Mugabe's desire for power is evident because he did not voluntarily

25 In the externalist camp are writers like Ali Mazrui, The Africans (London: BBC, 1986). In the internalist camp are writers like Nobel laureate Wole Soyinka, Ayi K. Armah, author of The Beautiful Ones Are Not Yet Born (Boston: Houghton Mifflin, 1968) and George B. N. Ayittey of Ghana, author of four books cited here: Indigenous African Institutions; Africa Betrayed; Africa in Chaos; and Africa Unchained.

26 Ayittey, Africa Unchained, xx.

27 Ibid., xxi.

28 See Ayittey's books especially the dedications to such affected individuals.

29 Even individuals struggled with the government. For example, once a patriotic singer, Thomas Mapfumo was exiled after he started singing songs about government corruption. Additionally, Strive Masiyiwa, founder and chairman of Econet Wireless Global Ltd. and Zimbabwe's richest man, contended with the government to get where he is today. Before establishing his wireless cell phone company, he had to take the 
abdicate the presidency but was deposed at the incredible age of 93 . His lengthy strong-man rule and the country's mounting political and economic problems seemed to have tarnished his reputation as a liberation hero both at home and abroad. Liberia also witnessed cases of strong-man rule under several warlords. ${ }^{30}$

The worst example of a corrupt African strong-man is the late Zairean (Democratic Republic of Congo) President Mobutu Sese Seko who was not only the richest man in Africa but also one of the richest in the world. Despite Zaire's grinding poverty, Mobutu's personal fortune was estimated at U\$D4-15 billion. ${ }^{31}$ In 1984, on CBS 60 Minutes, Mobutu boasted that he was "the second richest man in the whole world." ${ }^{32}$ He ruled Zaire for 32 years (1965-1997), ran a totalitarian regime or a kleptocracy and amassed his vast personal fortune. In 2011, Time Magazine called him "the archetypal African dictator." ${ }^{33}$ Mobutu created a personality cult that was evident in his many names and titles. ${ }^{34}$

More recent cases of African strongmen abound. For example, Colonel Muammar Gaddafi of Libya ruled for 32 years (1969-2011). He was overthrown in a 2011 NATO invasion of Libya and a rising wave of protest. Rebel fighters entered the capitol of Tripoli in August 2011 and occupied Green Square. The fighting (on 20 October 2011) ended with the public capture, humiliation and

government to court. Mugabe tried to shut him down when the opposition took advantage of his network to register protest. Masiyiwa even fled to South Africa for safety. Now he is a successful billionaire with a net worth of $\$ 2.3$ billion. See profile [cited 15 January 2021]. Online: https://en.wikipedia.org/wiki/Strive_Masiyiwa. In 2005, Ayittey predicted the end of Mugabe's regime but it did not materialise until 12 years later in 2017.

30 Ayittey, Africa Unchained, 422-423. Another case of strong-man rule is the prolonged 1995 Liberian war in which several warlords (Charles Taylor, Prince Johnson, Roosevelt Johnson and Alhaji Kromah) battled one another for the presidency after Samuel Doe's murder in September 1990. The bright side of that conflict was the election of Ellen Johnson Sirleaf as Africa's (and Liberia's) first woman president in 2006. She brought the civil war to an end during her 12-year tenure (2006-2018).

31 The Washington Times, 4 January 1997, A8, cited in Ayittey, Africa in Chaos, 150. See also Ayittey, Africa Betrayed, 254.

32 Ayittey, Africa Unchained, 213. With his family and friends from his ancestral homeland, Mobutu commanded real fabulous wealth. Zaire imploded in 1997 and Mobutu was overthrown by Laurent Kabila who in turn was assassinated in 2001 in another uprising and succeeded by his son Joseph Kabila.

33 Ishaan Tharoor, "Mobutu Sese Seko: Top 15 Toppled Dictators," Time Magazine (20 October 2011).

34 See Richard Dowden, Africa: Altered States, Ordinary Miracles (New York: PublicAffairs, 2010), 78-79, 353-379. On TV, he descended through the clouds like a god; his portraits were everywhere including on coins; his titles included: "Father of the Nation," "Messiah," "Guide of the Revolution," "Helmsman," "Founder," "Savior of the People," and "Supreme Combatant." See also article [cited 6 May 2020]. Online: https://en.wikipedia.org/wiki/Mobutu_Sese_Seko\#cite_note-time.com-5. 
execution of Gaddafi. About 30,000 Libyans were killed and 50,000 wounded in that revolution. ${ }^{35}$ Like Mugabe, Mobutu and Gaddafi were also long-time, powerful and influential strongmen who were toppled for their misrule.

One explanation of the behaviour of African strongmen is the so-called "pedagogy of the oppressed." ${ }^{36}$ Emerging from an oppressive colonial context, African leaders have internalised the behaviour of the oppressor and in turn become the new oppressors. This is because "the behavior of the oppressed is a prescribed behavior, following as it does the guidelines of the oppressor." 37 While the male African rulers discussed were powerful, corrupt, violent, clung to power and acted as strongmen, they also exhibited some of the defining traits of masculinity and the problems associated with a strong-man leadership model.

Accordingly, toxic behaviours of such African leaders illustrate the larger cultural, political and real-life consequences for feminist biblical interpreters who idealise female biblical characters as strong-man figures. Strong-man biblical women are not better men but problematic and even dangerous political figures.

\section{THE STRONG-MAN MODEL IN FEMINIST, WOMANIST AND POSTCOLONIAL BIBLICAL STUDIES}

The problem of a strong-man leadership model contributing to toxic masculinity also exists in feminist biblical interpretations that interpret female characters as strong men or "better men." This analysis criticises the strong-man leadership model that feminist interpreters admire and use to characterise female biblical characters. Select feminist interpretations exemplify this tendency in the field of biblical studies. Among the biblical women discussed herein are Sarah and Hagar (Gen 16:1-16; 21:8-21), Yael (Judg 4:17-24; 5:24-31) and Rahab (Josh $2: 9-13) .^{38}$

35 See profile [cited 6 March 2020]. Online: https://en.wikipedia.org/wiki/Muammar_Gaddafi.

36 See Paulo Freire, Pedagogy of the Oppressed (New York: The Continuum Publishing Corporation, 1988).

37 Freire, Pedagogy of the Oppressed, 31.

38 To date, much feminist work dealing with women characters in this section and the next has transpired. Books, commentaries, articles and Bible translations influenced by feminist, womanist, postcolonial and global perspectives are well documented. I will note just a few: Elisabeth Schüssler Fiorenza, In Memory of Her: A Feminist Theological Reconstruction of Christian Origins (New York: Crossroad, 1986); Luise Schottroff and Marie-Theres Wacker, eds., Feminist Biblical Interpretation: A Compendium of Critical Commentary on the Books of the Bible and Related Literature (Grand Rapids: William B. Eerdmans, 2012); Musa Dube, ed., Other Ways of Reading: African Women and the Bible (Atlanta: Society of Biblical Literature, 2001); Musa W. Dube, Postcolonial Feminist Interpretation of the Bible (St. Louis: Chalice Press, 
Genesis 16 narrates the complicated story of Abram, Sarai his barren wife and Hagar the Egyptian handmaid (shifhah שְְִָׁזָה continues in Gen 21, Hagar is referred to as the female slave ('amah אָָָָ) of Abraham. Abram's name is changed to Abraham (the father of many nations) in Gen 17:5 and Sarai's name is changed to Sarah in Gen 17:15 where God promises that she would become a mother of nations.

The narrative begins with the stated problem that Sarai was barren and had not borne children to Abram. It seems the responsibility to produce children lies with the woman. Her solution is to give Hagar to Abram as a wife so she can bear children for Abram on behalf of Sarai. Like a man that must ensure progeny, Sarai takes action to ensure that her problem is resolved. While some scholars focus on the idea of surrogate motherhood or wife substitution, Vanessa Lovelace unequivocally claims, "What happened to Hagar is rape." 39 When Hagar conceives, she looks upon her mistress with contempt and Sarai complains to Abram who authorises that she deals with her as she pleases. According to Mbuwayesango, Abram can correct whatever is wrong between Sarah and Hagar

2000); Daniel Patte, ed., Global Bible Commentary (Nashville: Abingdon Press, 2004); Elsa Tamez, Bible of the Oppressed (trans. Matthew J. O'Connel; Maryknoll: Orbis Books, 1987); Janice C. Anderson and Stephen D. Moore, eds., Mark and Method: New Approaches in Biblical Studies (Minneapolis: Fortress Press, 1992); Phyllis Trible, God and the Rhetoric of Sexuality (Philadelphia: Fortress Press, 1978); idem., Texts of Terror: Literary-Feminist Readings of Biblical Narratives (Philadelphia: Fortress Press, 1984); Renita Weems, Just a Sister Away: A Womanist Vision of Women's Relationships in the Bible (Philadelphia: Innisfree Press, 1988); idem., Battered Love: Marriage, Sex, and Violence in the Hebrew Prophets (Minneapolis: Fortress Press, 1995); Letty M. Russell, ed., Feminist Interpretation of the Bible (Philadelphia: Westminster, 1985); Nyasha Junior, An Introduction to Womanist Biblical Interpretation (Louisville: Westminster John Knox Press, 2015); Wilda C. Gafney, Womanist Midrash: A Reintroduction to the Women of the Torah and the Throne (Louisville: Westminster John Knox Press, 2017); Mitzi Smith, ed., I Found God in Me: A Womanist Biblical Hermeneutics Reader (Eugene: Wipf and Stock Publishers, 2015); Mitzi Smith and Mark A. Powell, eds., Insights from African American Interpretation: Reading the Bible in the 21st Century: Insights (Minneapolis: Fortress Press, 2017); Susanne Scholz, ed., Feminist Interpretation of the Hebrew Bible in Retrospect Vol I: Biblical Books (Sheffield: Sheffield Phoenix, 2013); Gale A. Yee, ed., The Hebrew Bible: Feminist and Intersectional Perspectives (Minneapolis: Fortress Press, 2019).

39 Vanessa L. Lovelace, “'This Woman's Son Shall not Inherit with My Son': Towards a Womanist Politics of Belonging in the Sarah-Hagar Narratives," The Journal of the Interdenominational Theological Center 41 (Spring 2015): 73. Gaiser, states: "The modern reader sees a violation of her person, perhaps even a kind of rape." See Frederick J. Gaiser, "Sarah, Hagar, Abraham-Hannah, Peninnah, Elkanah: Case Studies in Conflict," Word \& World Volume 34/3 (2014): 275; and Elizabeth Durant, "It's Complicated: Power and Complicity in the Stories of Hagar and Sarah," Conversations with the Biblical World Xxxv (2015): 78-93. 
for he is the cause of their rift but Abram shifts responsibility to her to do as she pleases with her, apparently rejecting Hagar as his wife. ${ }^{40}$ Sarai deals harshly with Hagar until she flees. Renita Weems sees a case of sexual exploitation in this scenario and Hagar's escape as a way of getting out of an abusive relationship. ${ }^{41}$

Having fled the home that she had known, Hagar is in a precarious situation. The angel of the Lord finds her and tells her to go back to Sarai and "submit to her" (Gen 16:9). The language of submission suggests domination by another, especially in an ancient patriarchal context where obedience was expected. In other words, Sarai is given more power and control over Hagar whom she had already oppressed. For Lovelace, "despite being a woman in a patriarchal society, Sarah still uses her privilege to subjugate and exploit Hagar." 42 Gaiser seems to suggest an apology for Sarai who has been empowered by both Abram and the angel. He states,

Not only must Hagar 'submit' to Sarai, but Sarai must 'submit' to whatever personal trauma is involved in living together with the mother of her husband's child. She must give up her vendetta against Hagar, and Abram will have to find a way to maintain peace in the family. ${ }^{43}$

The text does not show Abram doing this but suggests that Hagar returned to Abram and Sarai because it is Abram who gives the child the name Ishmael that was put forward by the angel. Abram's weakness and Sarai's power and control will also be shown in Gen 21:8-21 when Abraham "casts out" Hagar and Ishmael at Sarah's request.

In addition to commanding submission, the angel also promises that Hagar shall have a son that would be called Ishmael since God has seen her affliction. Scholars note that this type of affliction ('anah עָנָּה) experienced by Hagar was the same type that Pharaoh inflicted upon the children of Israel during their servitude. ${ }^{44}$ Many scholars note the significance of the name that Hagar gives to God, El Roi (God of my seeing). According to James Okoye, "she is the first and only person in the Bible to name God." 45 This first part ends with the note that "Hagar bore Ishmael to Abram" when he was eighty-six years old (Gen

40 Dora R. Mbuwayesango, "Childlessness and Woman-to-Woman Relationships in Genesis and in African Patriarchal Society: Sarah and Hagar from a Zimbabwean Woman's Perspective (Gen 16:1-16; 21:8-21)," Semeia 78 (1997): 31.

41 Weems, Just a Sister Away, 13.

42 Lovelace, "This Woman's Son," 70.

43 Gaiser, "Sarah, Hagar, Abraham," 276.

44 James C. Okoye, "Sarah and Hagar: Genesis 16 And 21," Journal for the Study of the Old Testament Vol 32.2 (2007): 168.

45 Okoye, "Sarah and Hagar: Genesis 16 and 21," 169. See also Durant, "It's Complicated," 88. 
16:15). This leads to the second story of conflict between Abraham and the two women in his life.

In Gen 21:1-7, Sarah gives birth to Isaac as the Lord had promised (Gen 17:15-19). However, the presence of two sons complicates the relationship between the two women as now the conflict has to do with the issue of inheritance. The Hebrew text says Sarah saw Ishmael playing (metsaheq מִִָּ [with] Isaac and she got upset. Scholars believe either Ishmael was playing with Isaac or playing the part or role of Isaac in a way that suggests displacing Isaac. For Lovelace, Ishmael was "“Isaacing' because... Sarah saw Ishmael behaving in some way as though he were still Abraham's patrilineal heir." 46 However, according to Mbuwayesango, since Isaac was the firstborn culturally slated for inheritance, the expulsion was "very unfair" because Hagar had fulfilled the most important requirement of patriarchy-childbearing. ${ }^{47}$

This incident occasions Sarah's second rage against Hagar. She demands

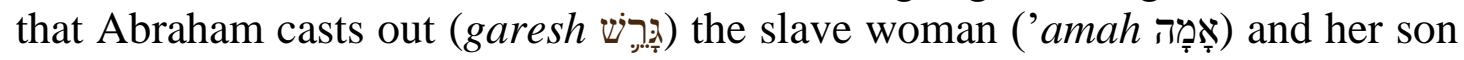
for Isaac could not inherit together with Ishmael. This incident once again illustrates the power of Sarah over both Abraham and Hagar. Although he was distressed, in a moment of curious divine intervention, God agrees with Sarah and tells Abraham to listen and do as Sarah says. Sarah's use of a term suggesting low social status ('amah אָָָָ) means "gender, ethnicity and class intersect here as a way to discriminate against Hagar and Ishmael."48 Sarah's expulsion of Hagar into the desert is literally "a sentence of death." 49

The entire narrative of Abraham, Sarah and Hagar illustrates the "manly" power and control of Sarah over Abraham, Hagar, the angel and indeed God. Even divine beings acquiesce to her wishes and desires. In the end, Sarah gets what she wants. Phyllis Trible comments on the larger implications of this narrative:

Hagar foreshadows Israel's pilgrimage of faith through contrast. As a maid in bondage, she flees from suffering. Yet she experiences exodus without liberation, revelation without salvation, wilderness without covenant, wanderings without land, promise without fulfillment, and unmerited exile without return. ${ }^{50}$

46 Lovelace, "This Woman's Son," 75.

47 Mbuwayesango, "Childlessness and Woman-to-Woman Relationships," 33.

48 Lovelace, "This Woman's Son," 75.

49 Gaiser, "Sarah, Hagar, Abraham," 279. Gaiser however questions God's will in this expulsion.

50 Phyllis Trible, Texts of Terror: Literary-Feminist Readings of Biblical Narratives (Philadelphia: Fortress Press, 1984), 28. 
While Sarah gets what she wants in the preceding narrative, the story of Yael and Sisera too illustrates a powerful woman who seems to be a "better man" female character than the man in question - the defeated, impotent and emasculated Canaanite general Sisera. This story is preserved in two places - in narrative form in Judges 4:17-24 and in verse form in Judges 5:24-31. Biblical scholars agree Judg 5 is one of the most ancient compositions in the Hebrew Bible. In this narrative, Yael functions as "an honorary man" ${ }^{11}$ who overpowers the supposedly powerful man and valiant warrior.

After the army of Sisera is routed completely by Deborah and Barak (Judg 4:1-16), Sisera flees on foot to the doomed tent of Yael, wife of Heber the Kenite, since the Kenites had good relations with Jabin the king of Canaan. Many interpreters agree the narrative is rife with sexual innuendo, deception and maternal themes, violent imagery, shame, honour and warrior motifs. ${ }^{52}$ The fleeing general arrives at the tent of Yael who comes out to meet him and the narrative hastens to dramatise his demise.

Critics note that in war situations, women were less likely to be combatants but victims, which most likely explains Yael's behaviour. While Yael invites Sisera into her tent, some believe that she had no hope of escape from a warrior who would most likely rape her, which drives her desire for survival. Fewell and Gunn argue that a man seldom enters a woman's tent without an intention of rape and her tent is symbolic of her body. One scholar is more categorical: "To take over the household Sisera must rape Jael to demonstrate that Heber cannot protect his women." 53

Yael ironically assures Sisera to "have no fear," deception that puts the general at ease and perhaps contemplating an easy conquest. When he asks for water, she gives him milk instead and according to Benjamin, "Sisera drinks the milk to prepare for sex; Jael serves the milk to prepare him for the sleep of death." 54 Twice in the narrative (vv. 18, 19), she covers him, perhaps to make

51 Gale A. Yee, "By the Hand of a Woman: The Metaphor of the Woman Warrior in Judges 4," Semeia (1993): 99-132. Here, Yee cites Matthew Henry's 1708 comments about the divine power that inspired Jael "with a more than manly courage" (emphasis added).

52 Yee, "By the Hand of a Woman,"; Elie Assis, "The Choice to Serve God and Assist His People: Rahab and Yael," Biblica 85/1 (2004): 82-90; Don C. Benjamin, "The Stories of Two Women: Rahab and Jael," The Bible Today (August 2013): 213-218; Danna N. Fewell and David M. Gunn, "Controlling Perspectives: Women, Men, and the Authority of Violence in Judges 4 \& 5," Journal of the American Academy of Religion LVIII/3, (1990): 389-411.

53 Benjamin, "The Stories of Two Women," 216. See also Fewell and Gunn, "Controlling Perspectives," 392. "Yael" and "Jael" are variant spellings of the same name because English normally uses the letter "J" for the Hebrew "Y."

54 Benjamin, "The Stories of Two Women," 217. 
him more comfortable. He asks her to stand guard at the door and to lie that there was no man if anyone inquired.

The deception continues and leads to the undoing of Sisera. As the tired general sleeps, Yael takes a tent peg and a workman's mallet and drives it through his temple or mouth. ${ }^{55}$ Judges 5 describes this part in very dramatic fashion (5:24-27). There is an inversion of roles or "reversed rape" in this text. ${ }^{56}$ According to Benjamin, "The man who penetrated the door of her tent is penetrated by the woman he threatened to penetrate." ${ }^{57}$ For Yee, "The author describes the killing scene as the reversal of rape (4:21). The man becomes the woman; the rapist becomes the victim; the penetrator becomes the penetrated. The tent peg in Jael's hands becomes synecdochically the ravaging phallus." 58

The deception and death of Sisera at the hand of a woman, Yael, is the ultimate undoing of a man by a woman who has suddenly acquired "manly" powers. In one fell swoop, Yael becomes the warrior, the man eater, the hunter, the victor and the one who dishonours and shames a man. According to Mieke Bal, Sisera is "un-manned" or shamed as Judg 4 describes what it means "to be or not to be a man." 59 In the poetic text that captures this scene, Susan Niditch sees "double meanings of violent death and sexuality" in every line and translates Judg 5:27 as follows: "Between her legs he knelt, he fell, he lay; between her legs he knelt, he fell; where he knelt, there he fell, despoiled." ${ }^{60}$ In biblical context, feet are also a euphemism for sexual organs. ${ }^{61}$

55 Fewell and Gunn state: "Patriarchal expectation is turned upside down as thewarrior's mouth is penetrated by an unmistakably phallic tent peg," see "ControllingPerspectives," 394. Fewell and Gunn translate the Hebrew רָ raqqâ (root רקק meaning "temple" (of mouth) on the basis of the same root which also means "spittle" or "spit," both associated with the mouth. They also cite several supporting studies. See Fewell and Gunn, "Controlling Perspectives," 393n11. See also Francis Brown, Samuel R. Driver and Charles A. Briggs, eds., The Brown-DriverBriggsHebrew and English Lexicon. With an Appendix Containing the Biblical Aramaic: Coded with Strong's Concordance Numbers. Based on the Lexicon of William Gesenius as Translated by Edward Robinson (Boston: Houghton Mifflin, 1906; Peabody: Hendrickson, Seventeenth Printing, 2017), 956.

56 Fewell and Gunn, "Controlling Perspectives," 394.

57 Benjamin, "The Stories of Two Women," 217.

58 Yee, "By the Hand of a Woman," 116.

59 Mieke Bal, Murder and Difference: Gender, Genre, and Scholarship on Sisera's Death (Bloomington: Indiana University Press, 1988), 118.

60 Susan Niditch, "Eroticism and Death in the Tale of Jael," in Gender and Difference in Ancient Israel (ed. Peggy L. Day; Minneapolis: Fortress Press, 1989), 47, 50.

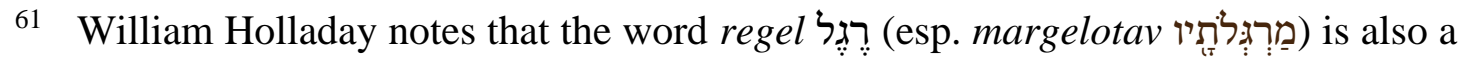
"euphem[ism] for [the] genital area," e.g., 2 Kgs 18:27; Isa 36:12, 7:20 and Ruth 3:4, 8, 14. See William L. Holladay, ed., A Concise Hebrew and Aramaic Lexicon of the 
Sisera's undoing at the hand of a woman makes him not only effeminate but Yael a "better man." Niditch describes Yael as "a warrior and seducer, alluring and dangerous, nurturing and bloodthirsty." 62 Double meaning is seen in her description of Sisera's failure and undoing: "He is at her feet in a pose of defeat and humiliation; he kneels between her legs in sexual pose. He falls and lies, a dead warrior assassinated by a warrior better than he." 63 Bal renders the final verdict on Sisera's un-manning and Yael's manliness: "The victory is here also that of a strong woman over a man who used to be strong. The woman, here, takes over the power and enjoys it." 64

As argued above, in the narrative of Yael and Sisera, feminist scholars tend to describe Yael as a powerful woman warrior, a strong-man female and indeed a better man. She uses deception and survival instincts and "out-mans" a seasoned war general. Her gender and social status are of no consequence in this patriarchal context where she may have remained a forgotten rape victim. The violence of war that is often associated with male warriors is placed on this female character to authenticate her. Her co-optation into a stereotypical male role for the benefit of Israel is the mark of her authenticity. Anne Létourneau essentially substantiates my argument in her essay where she argues that Yael is not really a representative of a heroine or subversive feminism but she is "reaffirming the heterosexist norm through this murder scene." 65 In addition, her sexualized graphic violence is "appropriated in a heterosexist way, for Israel's interests." $" 66$ We will next consider the example of Rahab, the Jericho prostitute who is also described as a 'better man' female in the book of Joshua.

The story of Rahab and the Israelite spies is the subject of Josh 2:1-24. Joshua has sent two spies to Jericho to reconnoiter the land. They arrive at the house of Rahab who hides them in her roof when the king of Jericho searches for them. In fact, she misleads her own people in order to save outsiders who would eventually kill her people and invade her land. She makes a pact with the spies where she vows to protect their mission in exchange for their protection of her and her family. Her speech is ironically a recitation of the mighty acts of Yahweh which have caused the inhabitants of the land to "melt" away in fear

Old Testament, Based upon the Lexical Work of Ludwig Koehler and Walter Baumgartner (Grand Rapids: William B. Eerdmans, 1971), 332.

62 Niditch, "Eroticism and Death," 45.

63 Ibid., 50 (emphasis added).

64 Mieke Bal, Death and Dissymmetry: The Politics of Coherence in the Book of Judges (Chicago: University of Chicago Press, 1988), 228.

65 Anne Létourneau, “Campy Murder in Judges 4: Is Yael a Gebérét (Heroine)?” in Gender Agenda Matters: Papers of the 'Feminist Section' of the International Meetings of the Society of Biblical Literature (ed. Irmtraud Fischer and Daniela Feichtinger; New Castle upon Tyne: Cambridge Scholars Press, 2015), 78.

66 Létourneau, "Campy Murder in Judges 4," 76. 
and dread (vv. 9, 11, 24). Rahab plays the part of the faithful foreigner and military strategist so well that readers should wonder why.

Many have read this story from the perspective of the biblical narrator. Rahab is the gentile woman whose exemplary faith, saves, aids and abets the people of God. One scholar notes that "usually women do not participate in war, but in these stories their actions are crucial in the implementation of the divine plan." ${ }^{67}$ As if to justify her defection, Elie Assis writes, "Rahab is a harlot and not an accepted member of society, which may explain her willingness to leave her own people and join another group." ${ }^{68}$ She unexpectedly helps Israel and her statement (Josh 2:9-11) is "one of the most awe-inspiring statements" of faith in the Bible. ${ }^{69}$

The usual conclusion is that "God often uses unanticipated and unexpected agents. God is sovereign over all and all humans are instruments to implement his plan." ${ }^{.70}$ One commentator avers, "Even more unusual is the fact that Rahab is more faithful to Yhwh than Joshua, and a better warrior." 71 Benjamin argues that "without her military skill and faithfulness the Hebrews would never have entered the land." 72 If readers put themselves in Rahab's shoes, one writer claims, "Our [Christian] origin lies not with the people who hear the command to kill, but with those who are to be killed."73

Other writers interpret the text differently. Biddle and Jackson argue that the spies are "stooges" and "buffoons" who accomplish nothing in a true spy story. They claim, "Joshua 2 is strangely a story in which 'nothing' really happens - there is no spying, no spy report, no suspenseful chase scene, no hardfought negotiation for one's life, and, finally, for the spies/messengers, there is no legacy." "74 Therefore, they conclude, "The church cannot arrogantly assume that the other has no blessing to offer. Rahab and the Israelites delivered each other." 75 While this may be true, however, such argument ignores the legacy of divinely sanctioned violence and genocide in the Bible (Josh 6:21; Deut 7:2).

67 Elie Assis, "The Choice to Serve God and Assist His People: Rahab and Yael," Biblica 85/1 (2004): 82-90 (86).

68 Assis, "The Choice to Serve God," 87.

69 Ibid., 87.

70 Ibid., 89.

71 Benjamin, "The Stories of Two Women," 214 (emphasis added).

72 Ibid., $215 \mathrm{f}$.

73 Phillip Cary, "We Are All Rahab Now," Christianity Today (July/August 2013): 28. Cary adds: "The truth is that much of the Bible will remain a closed book to us until, like Rahab, we enter into a relationship of lovingkindness with the people of Israel," 29.

74 Mark E. Biddle and Melissa A. Jackson, "Rahab and Her Visitors: Reciprocal Deliverance," Word \& World 373 (2017): 230.

75 Biddle and Jackson, "Rahab and Her Visitors," 233. 
More importantly, it discounts the legacy of colonialism and imperialism, the history of global Christianity and the use of such biblical texts to subjugate foreign lands and peoples. ${ }^{76}$

The use and function of biblical texts vary with context. Reading the Rahab narrative from a non-western and postcolonial context opens up different interpretive overtures to this famous biblical text. For example, Judith McKinlay reads this text as an outsider, from the twentieth century context of Aotearoa New Zealand and wonders whether Rahab is a saviour, traitor or victim of the story. ${ }^{77}$ While Rahab has power over the spies, McKinlay argues that her power is of the desperate marginalised underside. ${ }^{78}$ She argues that Rahab parrots Deuteronomistic theology better than the Israelites themselves, suggesting the hand of an editor. Her heroism is questionable because she hands over her own people to a foreign power. She is a marginalised Other, a woman and a foreigner, in addition to her morally questionable profession. However, in Israelite eyes, she is a hero who can sell her own people and sleep at night. ${ }^{79}$

Reading Rahab as the Other, Mckinlay argues that "Rahab sounds like an Israelite, for she is an Israelite construct and constructed as a pawn of the text which makes her into the all-important Other and so a significant part of the justification for the dispossession of her people's land." 80 She concludes that if Rahab is a hero/ine, not only are the Canaanites in danger but readers as well because,

[S] uch a view may also lead those who have lost their land to Christian invaders and settlers to read against their own history and identity.... They will then be reading with this Israelite agent Rahab, surrendering themselves unquestioningly to this world view. ${ }^{81}$

Reading Rahab from a postcolonial perspective also shows that Rahab is no heroine. Postcolonial biblical interpretation takes seriously the context of

76 See Dube, Postcolonial Feminist Interpretation; Pui-lan Kwok, Postcolonial Imagination and Feminist Theology (Louisville: Westminster John Knox Press, 2005); R.S. Sugirtharajah, The Bible and the Third World: Precolonial, Colonial and postcolonial Encounters (Cambridge: Cambridge University Press, 2001); idem., Postcolonial Reconfigurations: An Alternative Way of Reading the Bible and Doing Theology (St Louis: Chalice Press, 2003); Robert A. Warrior, "A Native American Perspective: Canaanites, Cowboys, and Indians," in Voices from the Margin: Interpreting the Bible in the Third World (ed. R.S. Sugirtharajah; Maryknoll: Orbis Books, 2000), 277-285.

77 Judith E. McKinlay, “Rahab: A Hero/ine?” Biblical Interpretation 7/1 (1999): 4457.

78 McKinlay, "Rahab: A Hero/ine?" 50.

79 Ibid., 50-53.

80 Ibid., 54.

81 Ibid., 56. 
colonialism and the ideology of power, domination and violence perpetrated by Empire on colonised people. Musa Dube applies a postcolonial feminist reading that not only exposes the negative side of colonialism but also reveals the cooptation of women to suit men's needs. Through this methodology, she interrogates the Bible and reveals the insidious role of gender, patriarchy and oppression. ${ }^{82}$ She argues that in the "contact zone," biblical descriptions of the conquest of Canaan are typical-the Canaanites are depicted as evil and unfaithful to God while Israel is portrayed as the faithful people of God. Therefore, Israel is to have nothing to do with the natives except kill them. Dube uses what she terms "Rahab's reading prism" to describe what takes place in the contact zone. Rather than viewing Rahab as a faithful helper of the Israelites as the text intimates, Dube decolonises her as a spy who assists the conquering enemy Israelites. Therefore, Rahab is a sell-out inasmuch as Pocahontas is. For instance, Dube states: "Pocahontas undoubtedly belongs to the creative pen of the colonizer." ${ }^{83}$ She adds that the coloniser uses the female body such as Rahab's to demonstrate desire and somebody to be possessed and used at will. She explains,

As a literary creation of the colonizer's pen, she [Rahab] is the mouthpiece of their agendas. The colonizer's ideal dream is that the colonized will proclaim the colonizer's superiority, pledge absolute loyalty, and surrender all their rights voluntarily... Rahab's story contains the somewhat hidden agenda of the colonizer that proceeds by characterizing the colonized as people 'who require and beseech to be dominated. ${ }^{84}$

Rahab is praised by the biblical writers; indeed, she is on the New Testament celebrated roll call of faithful heroes and heroines of old. Hebrews 11:31 recounts her story as follows: "By faith Rahab the prostitute did not perish with those who were disobedient, ${ }^{85}$ because she had received the spies in peace" (NRSV). Both the Deuteronomistic writer and the anonymous author of the book of Hebrews glorify her deeds because she succumbs to patriarchal and imperial desires and conforms to the expectations of dominant ideology and the master

82 See Dube, Postcolonial Feminist Interpretation, 11, 47, 56, 63, 69-70, 118 who also adds that imperial conquest narratives are ultimately about the four G's: God, Gold, Glory and Gender. See also a collection of essays on postcolonial biblical interpretations by continental and diasporic African scholars in Musa W. Dube, Andrew M. Mbuvi and Dora R. Mbuwayesango, eds., Postcolonial Perspectives in African Biblical Interpretations (Global Perspectives on Biblical Scholarship 13; Atlanta: Society of Biblical Literature, 2012).

83 Dube, Postcolonial Feminist Interpretation, 73.

84 Ibid., 78 (emphasis original).

85 The NRSV inserts a note that says, "or unbelieving." See Walter J. Harrelson, ed., The New Interpreter's Study Bible: New Revised Standard Version with the Apocrypha (Nashville: Abingdon Press, 2003), 2167 note 0. 
narrative. It is clear that Rahab expedites the conquest narrative by her cooptation as the faithful heroine who assists the conquering Israelites. Postcolonial feminist interpretation cautions readers to be suspect of biblical texts that sound too good and inspiring.

In the larger scheme of things and despite her problematic nature, Rahab comes out as the better man female, the better hero/ine and the better warrior. She fulfils the spies' mission and enables the slaughter of her own people and the taking of their land. She is celebrated and canonised for a reason. She has a strong and unshakeable faith and opens the floodgates of conquest for the people of God. She is a better spy and military strategist than Joshua.

Sarah, Yael and Rahab, all notable biblical women, provide models of toxic strong-man female leadership in feminist interpretation.

\section{DOES FEMINIST STUDIES HAVE TO BE CO-OPTED BY THE STRONG-MAN MODEL?}

This section offers two examples of biblical women who serve justice in the world without being interpreted as toxic male leaders to illustrate that feminist biblical interpreters do not need to read women characters as strong-man characters. It demonstrates how to read the selected biblical women characters without reinforcing the toxic strong-man leadership model. The section thus offers feminist biblical scholars an alternative model that helps to avoid the idealisation of strong-man women. Among the female characters considered are Jezebel (1 Kgs 16:29-34; 21:1-29; 2 Kgs 9:30-37) and Abigail (1 Sam 25:142).

Jezebel is the most notorious woman in the Bible and in popular culture and to be called a Jezebel is no compliment. ${ }^{86}$ The Bible describes her as the foreign wife of King Ahab of the Northern kingdom of Israel. As the daughter of King Ethbaal of the Sidonians (1 Kgs 16:31), she is a true Phoenician princess married to an Israelite king. Her tenure in Israel is characterised by conflict, hatred and an ignominious ending. She is the quintessential example of an evil woman in the Bible. However, was she really that bad? The answer depends on the perspective of the reader.

From the viewpoint of the biblical narrator who is a fervent Yahwist, Jezebel represents everything evil and undesirable about foreign women. Her credentials and accomplishments do not matter to the Israelite writer because rarely is anything good said about outsiders or the other. Typically, the other is the literary foil of the self. With few exceptions in the Bible, not much good is said about non-Israelites, be they characters or their nations. Often, the other is lifted up as an exemplary exception to the norm or the epitome of evil. In most cases, the other is simply different and bad. Jezebel falls into this latter category

86 See Tina Pippin, “Jezebel Re-Vamped” Semeia 69-70 (1995): 230. 
as the Deuteronomistic historian describes her as the evil foreign woman who leads faithful Israelite men astray. In the end, her demise is exceptional because it serves as an example of what happens to foreigners who pollute the holiness and integrity of God's people. Melissa Jackson argues,

By placing Jezebel so plainly in the role of 'foreign wife and faithful Baal-worshipper,' the Bible flattens Jezebel out, and she becomes little more than a trope-a caricature who serves only to bear the castigation and ridicule of the biblical text and its interpreters. ${ }^{87}$

Read against the grain and from the perspective of a princess in a foreign land, Jezebel emerges as a powerful queen who can take matters into her own hands and solve problems for her sulking husband. According to Jackson, "Jezebel is a powerful monarch... [and] a force to be reckoned with." ${ }^{88} \mathrm{Her}$ power is displayed in her contest and struggle with the frightened Yahwistic prophet Elijah (1 Kgs 19:1-3). To demonstrate her stature, 1 Kgs 18:19 confirms that the 450 prophets of Baal and the 400 prophets of Asherah ate at Jezebel's table. In other words, Jezebel was so powerful that she supported 850 Canaanite prophets. In addition, King Ahab also erected altars of worship to her foreign gods for which she is roundly condemned by the Deuteronomistic historian (1 Kings 16:32-33). The accommodation of such foreign worship in Israel points to some level of tolerance and a form of religious pluralism that was practiced in ancient Israel. However, it is this very idea for which Ahab and Jezebel are vilified by the biblical historian.

Jezebel's power is also shown in her ability to destroy the prophets of the Lord with the exception of only a hundred (1 Kgs 18:13). The conflict on Mount Carmel with Elijah leads to the killing of Jezebel's prophets, which enrages her. Her power shines when Elijah flees after she threatens his life (1 Kgs 19:3).

The story of Naboth's vineyard in $1 \mathrm{Kgs} 21$ demonstrates Jezebel's ultimate power and control over persons and situations. When Naboth refuses to sell his vineyard to King Ahab because it is his due inheritance, Jezebel plans and carries out his death and delivers the vineyard to her husband. As a foreign princess, she is obviously not bound by Israel's land tenure laws where land is inherited within families. Despite the evil act of killing and land seizure, Jezebel operates as a typical oriental monarchy with a different set of laws for land acquisition. Though her action is inexcusable, it demonstrates her power and control. It is also notable that Ahab neither questions Jezebel nor chastises her for her deeds, although Elijah blames him (1 Kgs 21:19).

Due to the power and challenge displayed by Jezebel, she meets an extremely gruesome death ( $2 \mathrm{Kgs} 9: 30-37)$. As Jehu comes to Jezreel, he has her

87 Melissa Jackson, "Reading Jezebel from the 'Other' Side: Feminist Critique, Postcolonialism, and Comedy," Review and Expositor 112/2 (2015): 245.

88 Jackson, "Reading Jezebel," 248. 
thrown from the window and her death is viewed as fulfilment of Elijah's prophecy (2 Kgs 9:36-37). When Jehu commands the burial of this foreign and hated princess, they only find her skull and extremities. The symbolism of this act is described by McKinlay as follows: "The writer wants his reader to understand that... this is one who has not acted her part as woman in Israel, and women who do not behave like women-according to this narrator's gender construction - must fall from their place." 89

Despite the negative description of Jezebel in both the Bible and popular culture, it can be concluded that Jezebel was indeed a powerful princess and queen who sought to preserve her culture and religion in a foreign place, the very thing which was her undoing. I will now turn to a discussion of Abigail and David.

The narrative about Abigail's encounter with David is recorded in 1 Sam 25:1-42. The story describes David's attempted extortion of Nabal, her husband, and how she intervenes on his behalf. That intervention may be interpreted as a wise decision that apparently saved Nabal from David's wrath. For the biblical narrator, however, the whole narrative saves David, the future king of Israel, from bloodguilt.

When David hears that the rich man Nabal is shearing sheep at Carmel, he sends his messengers to request payment for his protection of Nabal's shepherds and their flocks. Apparently oblivious of David's identity, Nabal rudely rebuffs them. David hears of it and he prepares to wipe out Nabal and his household.

In the meantime, Abigail learns about Nabal's foolish act and rushes to correct the offence and avert disaster. She prepares provision for David and brings it to him without telling her husband Nabal. She encounters David on his way to Nabal's house and pleads with him not to carry out his plan against Nabal. She indeed confirms that Nabal acted as a fool because his name means fool (1 Sam 25:25) and even takes the blame for her husband's foolishness. Ellen J. Van Wolde says in good British English, "he is a bloody idiot." 90 Abigail also convinces David not to incur bloodguilt and is even "prophetic" about David as

89 Judith E. McKinlay, Reframing Her: Biblical Women in Postcolonial Focus (Bible in the Modern World 1; Sheffield: Sheffield Academic Press, 2004), 81-82. Cat Quine agrees thus: "As she falls from window to gate she falls from queen to less than a person, and, if her presence at the window mirrors a goddess, then the goddess ideas and imagery fall with her, to be crushed under the hooves of Jehu's horses at the behest of Yahweh himself, in the place of his judgment. Her chaotic and unjust rule is ended and a new order, sanctioned by Yahweh, can now begin"; Cat Quine, "On Dying in a City Gate: Implications in the Deaths of Eli, Abner and Jezebel," Journal for the Study of the Old Testament 40/4 (2016): 412.

90 Ellen J. van Wolde. "A Leader Led by a Lady: David and Abigail in I Samuel 25," Zeitschrift für die alttestamentliche Wissenschaft 114/3 (2002): 362. 
the future prince of Israel (1 Sam 25:30). Van Wolde states, "An important aspect of Abigail's prophetic message is that she tells David of his identity as nāgîd over Israel." 91 This future role of David will eventually be realised when David becomes king but one wonders how Abigail was able to predict this. This may be how the narrator tries to portray Abigail as not only wise but prophetic. Indeed, she foresees what would have happened to her household, something that Nabal completely misses. David accepts the gifts and retreats while Abigail goes back home, having averted disaster upon her household. Amy Carman argues that,

After her husband insults David, she is able to mediate a peaceful outcome to the situation that benefits the majority of her household, David, and Israel. Her actions are approved by the other characters, impress David, and are blessed by Yahweh. ${ }^{92}$

Abigail tells her drunken but now sober husband about what she had done and the text says his heart died within him and he became like a stone. Ten days later, he was dead (vv. 36-38). When David hears about Nabal's demise, he views it as God's appropriate judgment upon Nabal's foolish act and insult that kept him from committing evil.

The narrative concludes with David wooing and taking Abigail as his wife. We are not told that Abigail refused him but she simply went with David's messengers and became his wife. It is rather fortuitous that David succeeds in extortion of Nabal's property, avoiding bloodguilt and acquiring both Nabal's property and wife. However, the text contrasts the wise and beautiful Abigail with her foolish and unthinking husband Nabal. It is only through Abigail's quick thinking, wit and wisdom that she averts the disasters that would have surely come upon her household.

Abigail's wisdom is evident in the entire story as a writer attests: "The narrator of 1 Samuel 25 characterizes Abigail as a sagacious woman who becomes the unforeseen savior of the future king. Unlike her foolish husband, Abigail is the embodiment of wisdom." "93 For Joyce Baldwin, "Abigail is master of the situation." ${ }^{94}$ Another commentator concludes,

The wealthy woman, whose social status suggests she does not need to be respectful to David the outlaw takes the inferior role ('slave'), and wins. She is the master of the situation. Her desperate plea has

91 Van Wolde, “A Leader Led by a Lady,” 367.

92 Amy S. Carman, “Abigail: The Wise Woman of Carmel," Stone-Campbell Journal 18 (Spring 2015): 59-60.

93 Carman, "Abigail," 59.

94 Joyce Baldwin, 1 and 2 Samuel: An Introduction and Commentary (TOTC; Leicester: IVP, 1988), 151. 
enabled her to capture Desperado David, the former pin-up celebrity boy, something that, ironically, King Saul has been unable to do. ${ }^{95}$

The text of 1 Sam 25 presents Abigail as the opposite of her man, a wise woman who takes charge of a potentially dangerous situation and diffuses a catastrophic ending. While David succeeds in committing extortion, the text writes an apology for him through the actions of this wise and thoughtful woman of Carmel. Abigail's description, actions and speech far surpass those of her husband Nabal and David himself. She is a less known character who plays a large role in this narrative. Feminist scholars continue to read these biblical texts about women from a variety of perspectives and social locations. ${ }^{96}$

\section{E CONCLUSION}

This essay has argued that the interpretation of biblical women as strongmen women is problematic and toxic. This problem exists in African political history where the strong-man leadership model is paradigmatic. It is very important to interpret biblical women in a non-toxic way by avoiding the strong-man model. The implications of reading biblical women in a non-toxic way and in the context of African political history have ramifications for biblical scholarship. It also offers androcentric biblical scholarship a way to not only read biblical men as the strong-man type but also as male leaders who lead in a non-strong-man fashion. A man does not have to be manly to be a man.

The strong-man leadership model exhibited by ancient African women (warrior queens) was deemed toxic because in that context, the women achieved their rule by displaying "manly" qualities as a model of their leadership. In fact,

95 Edward J. Bridge, "Desperation to a Desperado: Abigail's Request to David in 1 Samuel 25," Australian Biblical Review 63 (2015): 27.

96 See Susanne Scholz, ed., Feminist Interpretation of the Hebrew Bible in Retrospect. Vol. I. Biblical Books (Sheffield: Sheffield Phoenix, 2013); idem, Feminist Interpretation of the Hebrew Bible in Retrospect. Vol. II. Social Location (Sheffield: Sheffield Phoenix, 2014); idem, Feminist Interpretation of the Hebrew Bible in Retrospect. Vol. III. Methods (Sheffield: Sheffield Phoenix, 2016); idem, The Bible as Political Artifact: On the Feminist Study of the Hebrew Bible (Minneapolis, MN: Fortress Press, 2017); idem, Introducing the Women's Hebrew Bible: Feminism, Gender Justice, and the Study of the Old Testament, (Bloomsbury: T\& T Clark, 2017) and Carol A. Newson and Sharon Ringe, eds., The Women's Bible Commentary (Louisville: Westminster/John Knox Press, 1992). See also Carol A. Newsom, Sharon H. Ringe and Jacqueline E. Lapsley, eds., Women's Bible Commentary (Twentieth Anniversary Edition; Revised and Updated; Louisville: Westminster John Knox Press, 2012). For a review of the three volumes on Feminist Interpretation of the Hebrew Bible in Retrospect, see "Reviewing Feminist Interpretation of the Bible in Retrospect (ed. Susanne Scholz). A Panel Discussion at the SBL 2017 Annual Meeting in Boston, (MA)," 1-43, (C) Scholz et al., Feminist Interpretation of the Bible in Retrospect - lectio difficilior February 2017 [cited 24 July 2020]. Online: http://www.lectio.unibe.ch. 
they acted, behaved, dressed and even sought to look like men. This leadership model was replicated and is still being perpetuated by modern African strongman rulers. These leaders preside over failed political and economic institutions due to corruption, repressive rule, kleptocracy and other abuses. Strong-man rule provides a cautionary background for feminist biblical scholars who interpret female characters as strong men or better men.

A few select texts were used to demonstrate this tendency in critical feminist biblical hermeneutics. The critique of the strong-man women leaders revolved around the interpretation of Sarah and Hagar, Yael and Rahab whom feminist scholars tend to valorise as "better men" women characters due to their notable exploits and accomplishments. Such an interpretation also has influenced some of the abuses in contemporary culture as readers seek to outdo these women characters. This essay sought to question whether feminist scholarship should be co-opted by such toxic leadership models.

As a result, two female biblical characters were discussed in a non-toxic way as an attempt to provide feminist scholars with a better model of leadership. The discussion sought to rehabilitate the maligned images of Jezebel and Abigail in order to urge feminist scholars to abandon the tendency to interpret women characters as "manly" or better men but as providing alternative leadership models especially when read in different social contexts.

The implications of this study are the potential ramifications of such a methodology on androcentric biblical scholarship and masculinity studies where the focus on "manly" qualities such as strength, violence, aggression, warfare, domination of others and killing are prized. What are the implications of not reading biblical men as the strong-man type but rather as male leaders leading in a non-strong-man fashion? The ramifications of such an approach could result in a transformative reading of the stories of biblical women and men.

\section{H BIBLIOGRAPHY}

Anderson, Janice C. and Stephen D. Moore, eds. Mark and Method: New Approaches in Biblical Studies. Minneapolis: Fortress Press, 1992.

Armah, Ayi K. The Beautiful Ones Are not Yet Born. Boston: Houghton Mifflin, 1968. Assis, Elie. "The Choice to Serve God and Assist His People: Rahab and Yael." Biblica 85. 1 (2004): 82-90.

Ayittey, George B. N. Indigenous African Institutions. Doobs Ferry: Transnational Publishers, 1991.

Africa Betrayed. New York: St. Martin's Press, 1992.

Africa in Chaos. New York: St. Martin's Press, 1998.

Africa Unchained: The Blueprint for Africa's Future. New York: NY: Palgrave Macmillan, 2005.

Bal, Mieke. Murder and Difference: Genre, Gender, and Scholarship on Sisera's Death. Indiana Studies in Biblical Literature. Bloomington: Indiana University, 1988. 
Death and Dissymmetry: The Politics of Coherence in the Book of Judges. Chicago: The University of Chicago, 1988.

Baldwin, Joyce. 1 and 2 Samuel: An Introduction and Commentary. TOTC. Leicester: IVP, 1988.

Benjamin, Don C. "The Stories of Two Women: Rahab and Jael." The Bible Today (2013): 213-218.

Biddle, Mark E. and Melissa A. Jackson. "Rahab and Her Visitors: Reciprocal Deliverance." Word \& World 37/3 (2017): 226-233.

Bridge, Edward J. "Desperation to a Desperado: Abigail's Request to David in 1 Samuel 25." Australian Biblical Review 63 (2015): 14-28.

Brown, Francis, Samuel R. Driver and Charles A. Briggs, eds. The Brown-DriverBriggs Hebrew and English Lexicon. With an Appendix Containing the Biblical Aramaic: Coded with Strong's Concordance Numbers. Based on the Lexicon of William Gesenius as Translated by Edward Robinson. Peabody: Hendrickson, 2017.

Carman, Amy S. “Abigail: The Wise Woman of Carmel.” Stone-Campbell Journal 18 (Spring 2015): 47-60.

Cary, Phillip. "We Are All Rahab Now." Christianity Today (July/August 2013): 27 29.

Clarke, John H. "African Warrior Queens." Pages 123-134 in Black Women in Antiquity. Edited by Ivan Van Sertima. London: Transaction Books, 1986.

Connell, R. W. Masculinities. Berkeley: University of California Press, 2005.

Creangă, Ovidiu and Peter-Ben Smit. Biblical Masculinities Foregrounded. Sheffield: Sheffield Phoenix, 2014.

Dowden, Richard. Africa: Altered States, Ordinary Miracles. New York: PublicAffairs, 2010.

Dube, Musa W. Postcolonial Feminist Interpretation of the Bible. St. Louis: Chalice Press, 2000.

ed. Other Ways of Reading: African Women and the Bible. Atlanta: Society of Biblical Literature, 2001.

Dube, Musa W., Andrew M. Mbuvi and Dora R. Mbuwayesango, eds. Postcolonial Perspectives in African Biblical Interpretations. Global Perspectives on Biblical Scholarship 13. Atlanta: Society of Biblical Literature, 2012.

Durant, Elizabeth. "It's Complicated: Power and Complicity in the Stories of Hagar and Sarah." Conversations with the Biblical World Xxxv (2015): 78-93.

Fewell, Danna N. and David M. Gunn. "Controlling Perspectives: Women, Men, and the Authority of Violence in Judges 4 \& 5." Journal of the American Academy of Religion LVIII/3 (1990): 389-411.

Fischer, Irmtraud and Daniela Feichtinger, eds. Gender Agenda Matters: Papers of the 'Feminist Section' of the International Meetings of the Society of Biblical Literature. New Castle upon Tyne: Cambridge Scholars Press, 2015.

Freire, Paulo. Pedagogy of the Oppressed. New York: The Continuum Publishing Corporation, 1988.

Gafney, Wilda C. Womanist Midrash. A Reintroduction to the Women of the Torah and the Throne. Louisville: Westminster John Knox Press, 2017.

Gaiser, Frederick J. "Sarah, Hagar, Abraham-Hannah, Peninnah, Elkanah: Case Studies in Conflict.” Word \& World 34/3 (2014): 273-284. 
Harrelson, Walter J., ed. The New Interpreter's Study Bible: New Revised Standard Version with the Apocrypha. Nashville: Abingdon Press, 2003.

History.Com Editors. Cited 30 March 2021. Online: https://www.history.com/topics/ancient-history/hatshepsut.

Hodgson, Dorothy L. and Sheryl A. McCurdy, eds. "Wicked" Women and the Reconfiguration of Gender in Africa. Social History of Africa. Portsmouth: Heinemann, 2001.

Holladay, William L., ed. A Concise Hebrew and Aramaic Lexicon of the Old Testament, Based Upon the Lexical Work of Ludwig Koehler and Walter Baumgartner. Grand Rapids: William B. Eerdmans, 1971.

Jackson, Melissa. "Reading Jezebel from the 'Other' Side: Feminist Critique, Postcolonialism, and Comedy." Review and Expositor 112/2 (2015): 239-255.

Junior, Nyasha. An Introduction to Womanist Biblical Interpretation. Louisville: Westminster John Knox Press, 2015.

Kwok, Pui-lan. Postcolonial Imagination and Feminist Theology. Louisville: Westminster John Knox Press, 2005.

Létourneau, Anne. “Campy Murder in Judges 4: Is Yael a Gebérét (Heroine)?” Pages 42-86 in Gender Agenda Matters: Papers of the 'Feminist Section' of the International Meetings of the Society of Biblical Literature. Edited by Irmtraud Fischer and Daniela Feichtinger. New Castle: Cambridge Scholars Press, 2015.

Lindsay, Lisa A. and Stephan F. Miescher, eds. Men and Masculinities in Modern Africa. Portsmouth: Heinemann, 2003.

Lovelace, Vanessa L. “'This Woman's Son Shall not Inherit with My Son': Towards a Womanist Politics of Belonging in the Sarah-Hagar Narratives." The Journal of the Interdenominational Theological Center 41 (Spring 2015): 63-82.

Mazrui, Ali. The Africans. London: BBC, 1986.

Moore, Stephen. “'O Man, Who Art Thou...?' Masculinity Studies and New Testament Studies." Pages 1-42 in New Testament Masculinities. Edited by Stephen D. Moore and Janice C. Anderson. Semeia 45. Atlanta: Society of Biblical Literature, 2003.

Moore, Stephen D. and Janice C. Anderson, eds. New Testament Masculinities. Semeia 45. Atlanta: Society of Biblical Literature, 2003.

Mbuwayesango, Dora R. "Childlessness and Woman-to-Woman Relationships in Genesis and in African Patriarchal Society: Sarah and Hagar from a Zimbabwean Woman's Perspective (Gen 16:1-16; 21:8-21)." Semeia 78 (1997): 27-36.

McKinlay, Judith E. Reframing Her: Biblical Women in Postcolonial Focus. Bible in the Modern World 1. Sheffield: Sheffield Academic Press, 2004. . "Rahab: A Hero/ine?" Biblical Interpretation 7/1 (1999): 44-57.

Murray, S. O. and W. Roscoe, eds. Boy-Wives and Female Husbands: Studies of African Homosexualities. New York: St Martin's Press, 1998.

Newsom, Carol A. and Sharon H. Ringe, eds. Women's Bible Commentary with Apocrypha. Expanded Edition. Louisville: Westminster John Knox Press, 1992, 1998.

Newsom, Carol A., Sharon H. Ringe and Jacqueline E. Lapsley, eds. Women's Bible Commentary. Twentieth Anniversary Edition. Revised and Updated. Louisville: Westminster John Knox Press, 2012. 
Obeng, Pashington. "Gendered Nationalism: Forms of Masculinity in Modern Asante of Ghana." Pages 192-208 in Masculinities in Modern Africa. Edited by Lisa A. Lindsay and Stephan F. Miescher. Portsmouth: Heinemann, 2003.

Okoye, James C. "Sarah and Hagar: Genesis 16 and 21." Journal for the Study of the Old Testament 32/2 (2007): 163-175.

Niditch, Susan. "Eroticism and Death in the Tale of Jael." Pages 43-57 in Gender and Difference in Ancient Israel. Edited by Peggy L. Day. Minneapolis: Fortress Press, 1989.

Patte, Daniel, ed. Global Bible Commentary. Nashville: Abingdon Press, 2004.

Pippin, Tina. "Jezebel Re-Vamped.” Semeia 69-70 (1995): 221-233.

Pressler, Titus L. Transfigured Night: Mission and Culture in Zimbabwe's Vigil Movement. Pretoria: University of South Africa Press, 1999.

Quine, Cat. "On Dying in a City Gate: Implications in the Deaths of Eli, Abner and Jezebel." Journal for the Study of the Old Testament 40/4 (2016): 399-413.

Redford, Donald B, ed., The Oxford Encyclopedia of Ancient Egypt. 3rd vol. Oxford: Oxford University Press, 2000.

Reh, Mechthild and Gudrun Ludwar-Ene, eds. Gender and Identity in Africa. Hamburg: Münster, 1995.

Rotberg, Robert I. and Miles F. Shore (collaborator). The Founder: Cecil Rhodes and the Pursuit of Power. Oxford: Oxford University Press, 1988.

Russell, Letty M, ed. Feminist Interpretation of the Bible. Philadelphia: Westminster, 1985.

Scholz, Susanne, ed. Feminist Interpretation of the Hebrew Bible in Retrospect Vol I: Biblical Books. Sheffield: Sheffield Phoenix, 2013.

.ed. Feminist Interpretation of the Hebrew Bible in Retrospect. Vol. II. Social Location. Sheffield: Sheffield Phoenix, 2014.

Feminist Interpretation of the Hebrew Bible in Retrospect. Vol. III. Methods. Sheffield: Sheffield Phoenix, 2016.

The Bible as Political Artifact: On the Feminist Study of the Hebrew Bible. Minneapolis: Fortress Press, 2017.

. Introducing the Women's Hebrew Bible: Feminism, Gender Justice, and the Study of the Old Testament. Bloomsbury: T\&T Clark, 2017.

Schottroff, Luise and Marie-Theres Wacker, eds. Feminist Biblical Interpretation: A Compendium of Critical Commentary on the Books of the Bible and Related Literature. Grand Rapids: William B. Eerdmans, 2012.

Schüssler Fiorenza, Elisabeth. In Memory of Her: A Feminist Theological Reconstruction of Christian Origins. New York: Crossroad, 1986.

Smit, Peter-Ben. Masculinity and the Bible: Surveys, Models, and Perspectives. Leiden: Brill, 2017.

Smith, Mitzi, ed. I Found God in Me: A Womanist Biblical Hermeneutics Reader. Eugene: Wipf and Stock, 2015.

Smith, Mitzi and Mark A. Powell, eds. Insights from African American Interpretation. Reading the Bible in the 21st Century: Insights. Minneapolis: Fortress Press, 2017.

Sugirtharajah, R.S. The Bible and the Third World: Precolonial, Colonial and Postcolonial Encounters. Cambridge: Cambridge University Press, 2001.

Postcolonial Reconfigurations: An Alternative Way of Reading the Bible and Doing Theology. St Louis: Chalice Press, 2003. 
Sweetman, David. Women Leaders in African History. African Historical Biographies. London: Heinemann, 1984.

Tamez, Elsa. Bible of the Oppressed. Translated by Matthew J. O'Connel. Maryknoll: Orbis Books, 1987.

Tharoor, Ishaan. "Mobutu Sese Seko: Top 15 Toppled Dictators." Time Magazine (20 October 2011).

Trible, Phyllis. God and the Rhetoric of Sexuality. Philadelphia: Fortress Press, 1978. Texts of Terror: Literary-Feminist Readings of Biblical Narratives. Philadelphia: Fortress Press, 1984.

Vander Stichele, Caroline and Todd Penner. Contextualizing Gender in Early Christian Discourse: Thinking Beyond Thecla. London: T\&T Clark, 2009.

Van Sertima, Ivan, ed. Black Women in Antiquity. London: Transaction Books. 1984, Fourth printing 1986.

Van Wolde, Ellen J. "A Leader Led by a Lady: David and Abigail in I Samuel 25." Zeitschrift für die alttestamentliche Wissenschaft 114/ 3 (2002): 355-375.

Warrior, Robert A. "A Native American Perspective: Canaanites, Cowboys, and Indians." Pages 277-85 in Voices from the Margin: Interpreting the Bible in the Third World. New Edition. Edited by R.S. Sugirtharajah. Maryknoll: Orbis Books, 2000.

Weems, Renita. Just a Sister Away: A Womanist Vision of Women's Relationships in the Bible. Philadelphia: Innisfree Press, 1988.

Battered Love: Marriage, Sex, and Violence in the Hebrew Prophets. Minneapolis: Fortress Press, 1995.

Wimby, Diedre. "The Female Horuses and Great Wives of Kemet." Pages 36-48 in Black Women in Antiquity. Edited by Ivan Van Sertima. New Brunswick: Transaction Books. 1984, Fourth printing 1986.

Yee, Gale A. "By the Hand of a Woman: The Metaphor of the Woman Warrior in Judges 4." Semeia (1993): 99-132. ed. The Hebrew Bible: Feminist and Intersectional Perspectives. Minneapolis: Fortress Press, 2019.

Dr. Robert Wafawanaka, School of Theology, Virginia Union University, Email: rwafawan@ vuu.edu. ORCID: https://orcid.org/0000-0002-6389-4545. 